\title{
A QUANTITATIVE MAPPING OF ALKALINE PHOSPHATASE IN THE BRAIN OF THE RHESUS MONKEY*
}

\author{
ReInhard L. Friede \\ Division of Neuropathology, Institute of Pathology, Western Reserve University, \\ Cleveland, Ohio; and Mental Health Research Institute, University of Michigan, \\ Ann Arbor, Mich.
}

(Received 4 June 1965)

ALKALINE phosphatase shows greater species variability than all other enzymes that have been studied histochemically in the brain. The pioneering studies by SHIMIzU (1950) demonstrated that activity of this enzyme in many species is concentrated mainly in the blood vessels, whereas in some species (e.g. in the rabbit and in several avian species) little or no activity occurs in the blood vessels, but marked activity is seen in the neuropil. In addition, exceptionally high degress of activity may occur in certain nuclei of a given species, such as the extremely high activity that is found in the habenular nucleus, the retroflex tract, and the interpedunclar nucleus in guinea pigs. SHImizu's data agree with those from several other less detailed investigations (LANDow, Kabat and Newman, 1942; Wislocki and DemPSeY, 1948; and others).

The present study reports a systematic, quantitative mapping of alkaline phosphatase activity in the brain of the rhesus monkey, paralleling a previous mapping of acid phosphatase in the same species (FRIEDE and KNoller, 1965b). The data obtained are of interest for two reasons: first, the use of a quantitative, histochemical method affords detailed data on ratios of relative enzyme activities in various regions of the brain; secondly, not only the regional distribution of enzyme activity but also the cytological distribution in any given region varied greatly in this species.

\section{MATERIALS AND METHODS}

Histochemical method: Preliminary testing and standardization of the quantitative method for alkaline phosphatase activity were done with cat and monkey brains (FrIEDE and KNOLLER, 1965a). For the present study, three healthy, adult, rhesus monkeys were killed under pentothal anaesthesia, and the brains were removed immediately. The procedures for fixation, preparation of tissue sections, and incubation were essentially the same as thosedescribed in the preceding report on acid phosphatase activity (FRIEDE and KNOLLeR, 1965b). The methods differ only in minor details; the substrate mixture consisted of $1 \mathrm{mg}$ of sodium naphthyl phosphate (from Sigma Chemical Co., St. Louis) and $1 \mathrm{mg}$ of 5-chloro-o-toluidine (Fast Red TR from Dajac Laboratories, Philadelphia) in $1 \mathrm{ml}$ of $0.1 \mathrm{M}$ tris buffer at pH 10 (PeArSE, 1961). Tissue discs were cut from selected areas of the stained brain sections, and the azo dye was extracted with chloroform-ethanol $(1: 1, \mathrm{v} / \mathrm{v})$. Colour densities were determined at $540 \mathrm{~m} \mu$ on a Beckman DU spectrophotometer. Ten discs were measured for every region reported in Table 1.

Biochemical method: Homogenates were prepared from seven regions of the brains of three rhesus monkeys. A modification of Gomori's (1949) phenol method was used for determination of alkaline phosphatase activity in crude homogenates; this method was nearly the same as that used for acid phosphatase activity (FrIEDE and KNOLLER, 1965a,b). Substrates consisted of $90 \mathrm{ml}$ of $0.1 \mathrm{M}$-borate buffer at $\mathrm{pH} 9 \cdot 8,10 \mathrm{ml}$ of approximately $0.05 \mathrm{M}$-disodium phenyl phosphate, and $1 \mathrm{ml}$ of $20 \% \mathrm{MgCl}_{2}$. Activities were measured in triplicate as $\mu \mathrm{g}$ phenol liberated per $\mathrm{mg}$ wet tissue per hour at $38^{\circ}$.

* This investigation was supported by U.S. Public Health Grants B 3250 and NB 6239 from the National Institute of Neurological Diseases and Blindness. 


\section{RESULTS}

Quantitative data. The quantitative histochemical method used in this study demonstrates reproducible ratios of relative enzyme activities in various regions of a given brain; the method is not suited for measurements of absoluteactivities, however, because such factors as the effects of fixation or the ratio of volume of sections to volume of incubation medium cannot be so well controlled as in homogenates of fresh tissue (FrIEDe and KNOLLER, 1965a). For this reason, regional activities have been

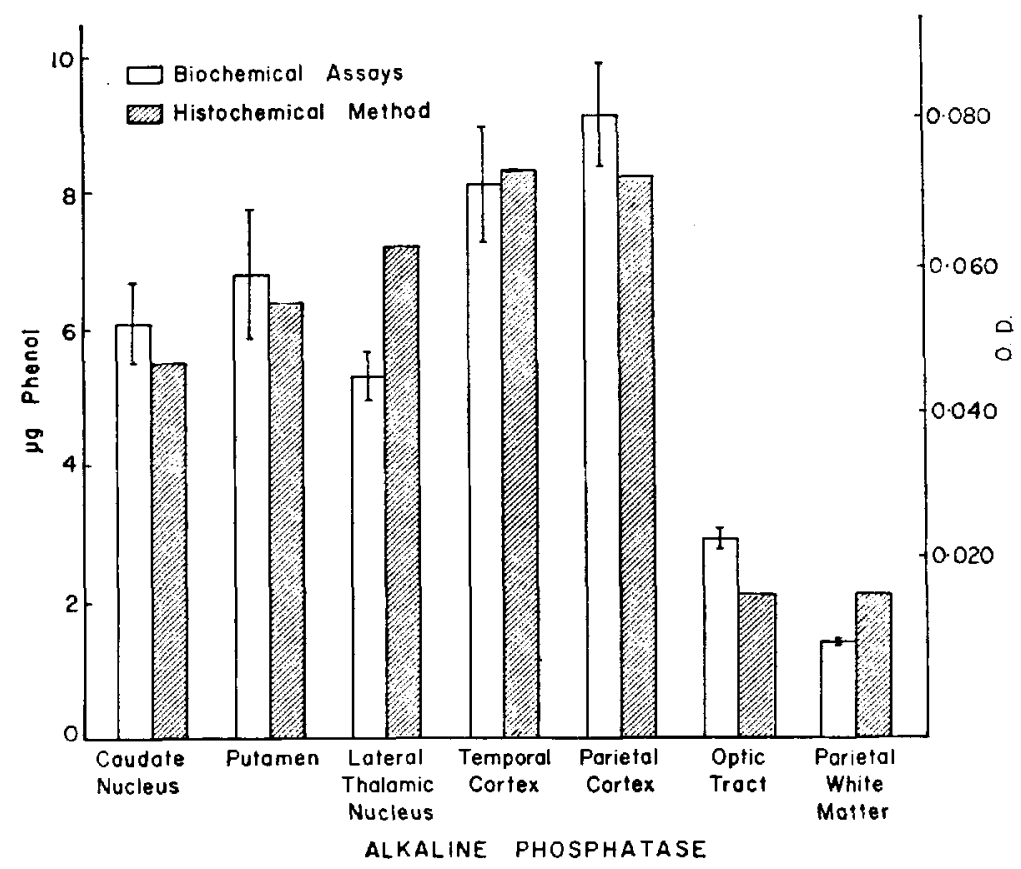

FIG. 1.-A comparison of quantitative histochemical measurements of regional activities of alkaline phosphatase with assays from the same regions with GoMORI's (1949) phenol method. Biochemical data are expressed as $\mu \mathrm{g}$ of phenol liberated per mg wet tissue per hour at $38^{\circ}$ Triplicate determinations were done for each region in three monkeys. Histochemical measurements refer to averages of ten measurements each in three monkeys.

expressed as percentages of the activities found in the putamen, rather than in terms of optical densities or amounts of dye, as was done in the previous report on acid phosphatase. That these ratios reflect true ratios of the enzyme activities present in the tissue was tested by comparing the activities obtained with the histochemical method with those found in assays of homogenates from homologous regions of monkey brains (Fig. 1). While some differences are evident, the general agreement of two sets of data is good. The reproducibility of data is also evident in a comparison of the measurements for the three monkeys. All sections shown in the illustrations are samples from the series in which quantitative measurements were taken.

Regional variation (Table 1) is much greater for alkaline phosphatase than for acid phosphatase activity (FRIEDE and KNOLLER, 1965b), both among different nuclei and between grey and white matter. Generally, the average ratio of activities in white matter and grey matter was 1.0:2.9 for acid phosphatase (FRIEDE and KNOLLER, 
Table 1.-Distribution of alkaline phosphatase activity in the BRain of THE RHESUS MONKEY

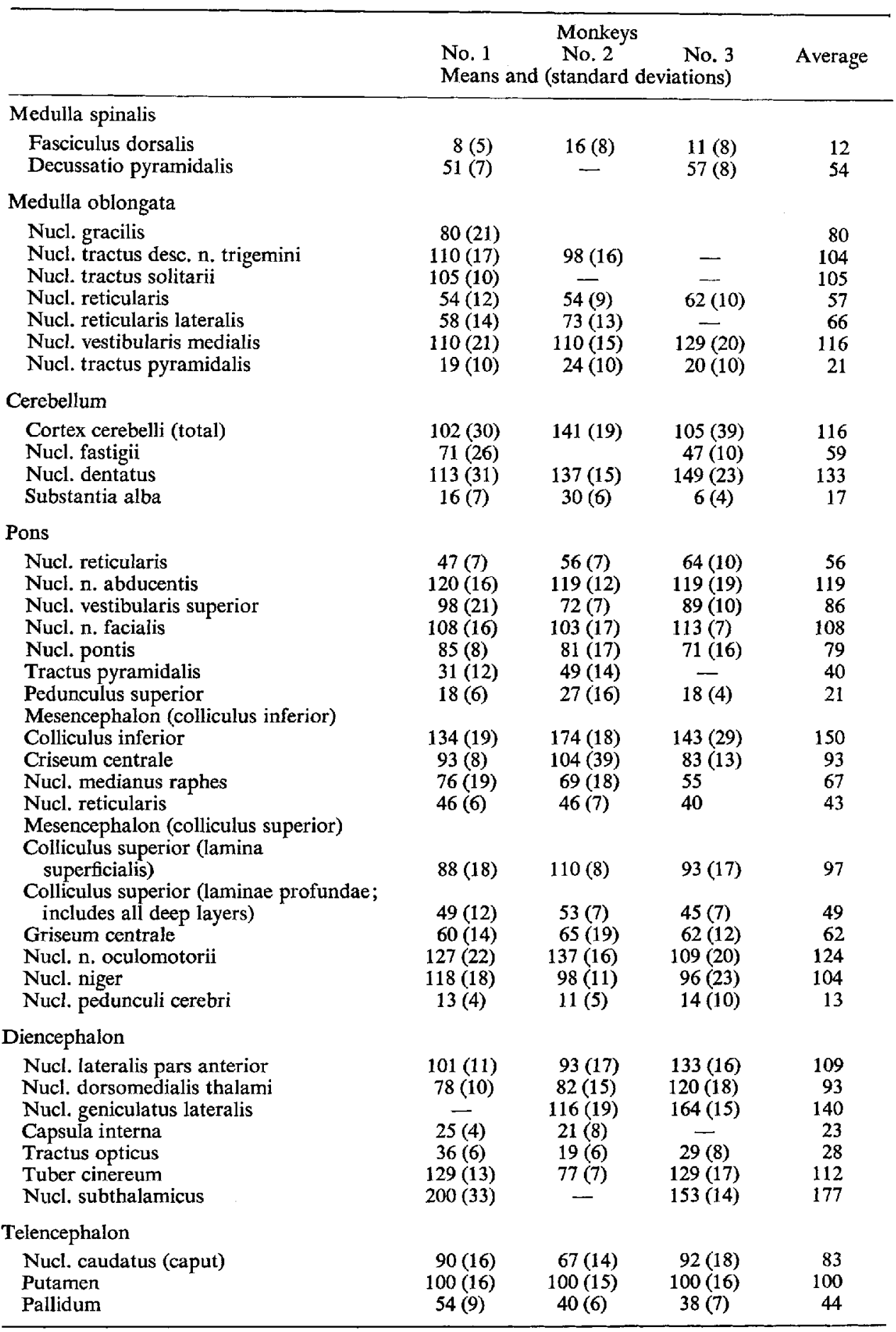


TABLE 1 (contd.)

\begin{tabular}{|c|c|c|c|c|}
\hline & $\begin{array}{l}\text { No. } 1 \\
\text { Means an }\end{array}$ & $\begin{array}{l}\text { Monkeys } \\
\text { No. 2 } \\
\text { (standard c }\end{array}$ & $\begin{array}{r}\text { No. } 3 \\
\text { iations) }\end{array}$ & Average \\
\hline \multicolumn{5}{|l|}{ Cortex precentralis } \\
\hline $\begin{array}{l}\text { Laminae II-IV } \\
\text { Substantia alba }\end{array}$ & $\begin{array}{c}128(25) \\
28(3)\end{array}$ & $\begin{array}{c}108(12) \\
17(6)\end{array}$ & $\begin{array}{l}161(13) \\
28(8)\end{array}$ & $\begin{array}{r}132 \\
24\end{array}$ \\
\hline $\begin{array}{l}\text { Cortex frontopolaris } \\
\text { Laminae II-IV } \\
\text { Laminae V-VI } \\
\text { Substantia alba }\end{array}$ & $\begin{array}{c}83(22) \\
166(6) \\
68(11)\end{array}$ & $\overline{-}$ & z & $\begin{array}{r}83 \\
166 \\
68\end{array}$ \\
\hline $\begin{array}{l}\text { Cortex parietalis } \\
\text { Laminae V-VI } \\
\text { Substantia alba }\end{array}$ & $\begin{array}{c}157(10) \\
29(7)\end{array}$ & $\begin{array}{r}156(14) \\
29(10)\end{array}$ & $\begin{array}{c}219(20) \\
43(6)\end{array}$ & $\begin{array}{r}177 \\
32\end{array}$ \\
\hline $\begin{array}{l}\text { Cortex occipitalis } \\
\text { Laminae II-III } \\
\text { Substantia alba }\end{array}$ & $\begin{array}{c}105(18) \\
9(5)\end{array}$ & $\begin{array}{c}117(14) \\
25(9)\end{array}$ & $\begin{array}{l}124(12) \\
23(5)\end{array}$ & $\begin{array}{r}115 \\
19\end{array}$ \\
\hline $\begin{array}{l}\text { Cortex temporalis } \\
\text { Laminae III-IV }\end{array}$ & $161(10)$ & $149(28)$ & $\begin{array}{l}168(17) \\
174(21)\end{array}$ & $159 / 161$ \\
\hline $\begin{array}{l}\text { Substantia alba } \\
\text { Cornu Ammonis (all layers) }\end{array}$ & $\begin{array}{c}45(5) \\
124(35)\end{array}$ & $\begin{array}{l}30(11) \\
72(12) \\
65(11)\end{array}$ & $\begin{array}{c}40(6) \\
103(20)\end{array}$ & $\begin{array}{c}35 \\
100 / 97\end{array}$ \\
\hline
\end{tabular}

All activities are expressed as a percentage of that in the putamen. The values are averages of measurements of the dye produced by the histochemical simultaneous azo coupling method, in three monkeys. Ten measurements were made for each region in each monkey.

\section{General averages}

Averages for eight regions providing pure samples of white matter 22

$\begin{array}{ll}\text { Averages for seven nuclei with many transfixing fibre bundles } & 69\end{array}$

$\begin{array}{ll}\text { Averages for twenty regions providing pure samples of gray matter } & 106\end{array}$

Same as above, but excluding samples of cerebral cortex 96

$\begin{array}{ll}\text { Averages for four regions of cerebral cortex } & 146\end{array}$

1965b), but that for alkaline phosphatase activities was 1·0:4.8 for all regions and $1 \cdot 0: 5 \cdot 0$ for subcortical whitematter and cerebral cortex. This ratio agrees well with that reported by ALBERT (1955) of 1.0:5.6 for human white matter to cortex. SAMORAJSKI and FITZ (1961) report a nearly tenfold difference in activity between the spinal tracts and spinal gray matter in rabbit; this finding seems consistent with the very low values (Table 1) for spinal dorsal tracts. Microchemical data by Lowry, ROBERTs, LEINER, WU, FARR and AlBers (1964) on rabbit Ammon's horn, and by RoBINS and SMITH (1953) on monkey cerebellum, are difficult to compare because they refer to activities per unit protein, or per unit lipid-free dry weight, respectively, rather than volume of tissue.

In all regions, individual measurements showed considerable variation, as can be seen by the very large standard deviations in Table 1 . This variability was not attributed to an inaccuracy of the method; rather, the size of the samples was such that the variable number of blood vessels included-especially the inclusion of a large arterial trunk-would result in considerable deviation from the mean. These sampling problems are clearly recognizable from inspection of the microphotographs. 
Histological data. (1) Activity in capillaries. Most alkaline phosphatase activity in monkey brain tissue was located in the capillaries and arterioles. Thus, regional variation in enzyme activity roughly paralleled the number of blood vessels present (Figs. 2 through 8).

Even a cursory inspection of the figures shows, however, that not all the blood vessels contained enzyme activity. Maximal activity was found in arterioles and in capillaries, but very little or none occurred in veins (SHIMIZU, 1950; BANNISTER and ROMANUL, 1963). In the present study, the density of vessels showing enzyme activity in the cerebral cortex (Fig. 7) did not approach the vascular density one finds in preparations of injected blood vessels. In the cerebellar cortex, vessels showing enzyme activity prevailed in the inner portion of the molecular layer, and the dense capillary network of the granular layer was only partly stained. Also, the blood vessels of the cerebellar dentate nucleus seemed to contain appreciably more activity per vessel than those of the cerebellar cortex (Fig. 3). Indeed, the ratio of activity for the Nucl. fastigii and Nucl. dentatus was $1 \cdot 0: 2 \cdot 3$ respectively, whereas the ratio of capillarization density for these nuclei in cat brain-which is probably similar to the ratio in monkey-is only 1.0:1·3 (FrIede, 1961).

In general, an even greater difference was found for the white matter and grey matter, for which the ratio of enzyme activities was 1.0:4.8, whereas ratios for capillarization reported in the literature usually range between $1: 2$ and 1:3 (See FrIEDE, 1961). Indeed, scanning of the sections at low power often revealed surprisingly large areas in the hemispheric white matter, or in spinal tracts, in which no blood vessels were demonstrated by enzyme activity (Fig. 2, 7). If enzyme preparations were counterstained with chrome alum gallocyanin, numerous blood vessels without enzyme activity became visible in those areas. Therefore, the relative proportion of the blood vessels containing enzyme activity appears to vary regionally.

The enzyme activity was usually sharply confined to the vascular walls, but sometimes staining spread into the perivascular tissue. This may suggest a diffusion artefact; vessels with and without perivascular activity were seen side by side, however, and larger veins were occasionally surrounded by cuffs of perivascular activity that were out of proportion to the very weak activity in the vessels (Fig. 6, arrows). Thus, one may question the concept that perivascular staining is a diffusion artefact.

(2) Activity in neuropil. In the majority of nuclei, alkaline phosphatase activity was confined almost entirely to the blood vessels and was absent from the neuropil. In the cerebral neocortex, however, enzyme activity did occur in the neuropil, being maximal in the superficial portion of the first lamina and in a layer at the level of the fourth and fifth lamina or the fifth lamina only (Fig. 7); the exact position and thickness of the latter layer varied regionally. Nerve cell perikarya always showed no activity.

Alkaline phosphatase activity in the neuropil was highest in all neocortical areas, especially in primary sensory areas; in the occipital cortex, a sharp decrease in activity was found at the borders of the visual area; no sharp borders were found between any other areas in the cortex, however. Allocortical areas showed less activity in the neuropil than did neocortical areas, and the Ammon's horn showed only a narrow zone of activity in the neuropil on both sides of the cell layer of the fascia dentata (Fig. 8).

Alkaline phosphatase activity in the cortical neuropil contrasted sharply with the absence of activity in the neuropil of the caudate nucleus (Fig. 6), putamen, and 
pallidum; in all the thalamic nuclei; and in the amygdala. This contrast was clearly visible by the darker overall staining of the cortex (Fig. 6) and was reflected by values about 50 per cent above the averages for grey matter (Table 1, bottom). The hypothalamus differed from the other subcortical centres in showing activity in the neuropil that nearly equalled that in neocortex; still higher activity occurred in the region of the supraoptic and paraventricular nuclei. In the brain stem, several other nuclei also contained marked activity in the neuropil as well as in their capillaries. Especially marked activity in the neuropil occurred in the oculomotor nucleus (Fig. 5) and in the terminal nuclei of the dorsal spinal tracts (Fig. 2); slightly less activity was found in the neuropil of the cerebellar dentate nucleus (Fig. 3), the inferior olivary nucleus (Figs. 2, 3), the hypoglossal nucleus (Fig. 2), the red nucleus, and the substantia nigra (Figs. 4, 5). Measurements in the oculomotor and dentate nuclei showed higher levels of activity in these nuclei (Table 1) than in those that contained little or no activity in the neuropil. Enzyme activity was absent from the area postrema (Fig. 2) and the pituitary stalk.

(3) Activity at the surface of brain tissue. As in previous reports (SHIMIZU, 1950), alkaline phosphatase activity was found to increase toward the outer surfaces of brain tissue; for example, the entire circumference of the brain stem was lined with a thin layer of increased alkaline phosphatase activity (Figs. 2-5). Also, this superficial zone of enzyme activity was continuous with the surface of emerging cranial nerves (Fig. 5) up to the level of the glia-Schwann cell junction where a zone of marked enzyme activity transversed the nerve, separating the central portion from the peripheral portion.

\section{DISCUSSION}

The biological significance of alkaline phosphatase is unknown. The complex regional and cellular distribution patterns revealed by histochemical methods make it even more difficult to interpret the distribution of this enzyme in terms of known physiological functions. The subtle details demonstrated by the present data compound rather than alleviate these difficulties.

Besides documenting the distribution patterns of alkaline phosphatase activity in the brain of the rhesus monkey, the present data may serve to illustrate the many pitfalls that can occur in the interpretation of data on regional distribution of enzyme activities without knowledge of their detailed cytological localization. For example, the overall regional pattern of alkaline phosphatase activity shows numerous similarities with regional patterns of the enzymes of oxidative metabolism. These similarities are purely coincidental, however, because rates of energy metabolism are generally paralleled by variation in the density of vascularization, and because alkaline phosphatase happens to be located mainly in blood vessels.

Moreover, the relative activities of alkaline phosphatase in cortex and putamen, for example, refer to different cellular patterns; roughly one-third of the cortical activity seems to be in neuropil, but nearly all of that of the putamen is in blood vessels. Other findings imply that blood vessels of various regions may differ as to their relative proportion of enzyme activity; in particular, fewer of the vessels of white matter seem to contain alkaline phosphatase activity than those of grey matter.

The apparent selective localization of alkaline phosphatase in blood vessels has stimulated speculation about the use of this enzyme for studying capillarization (SCHARRER, 1950); LIERSE (1963), for example, used histochemical stains for alkaline 


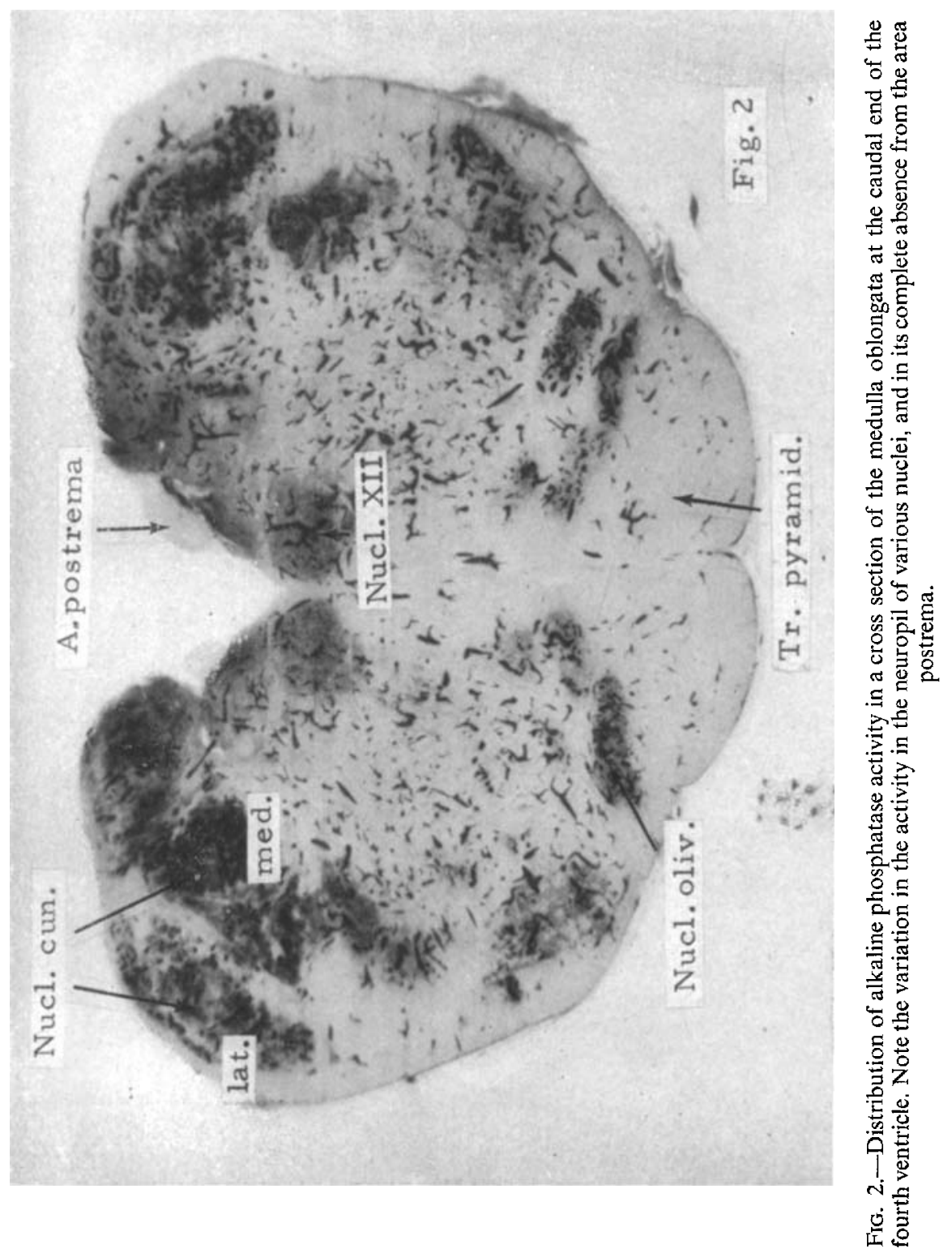




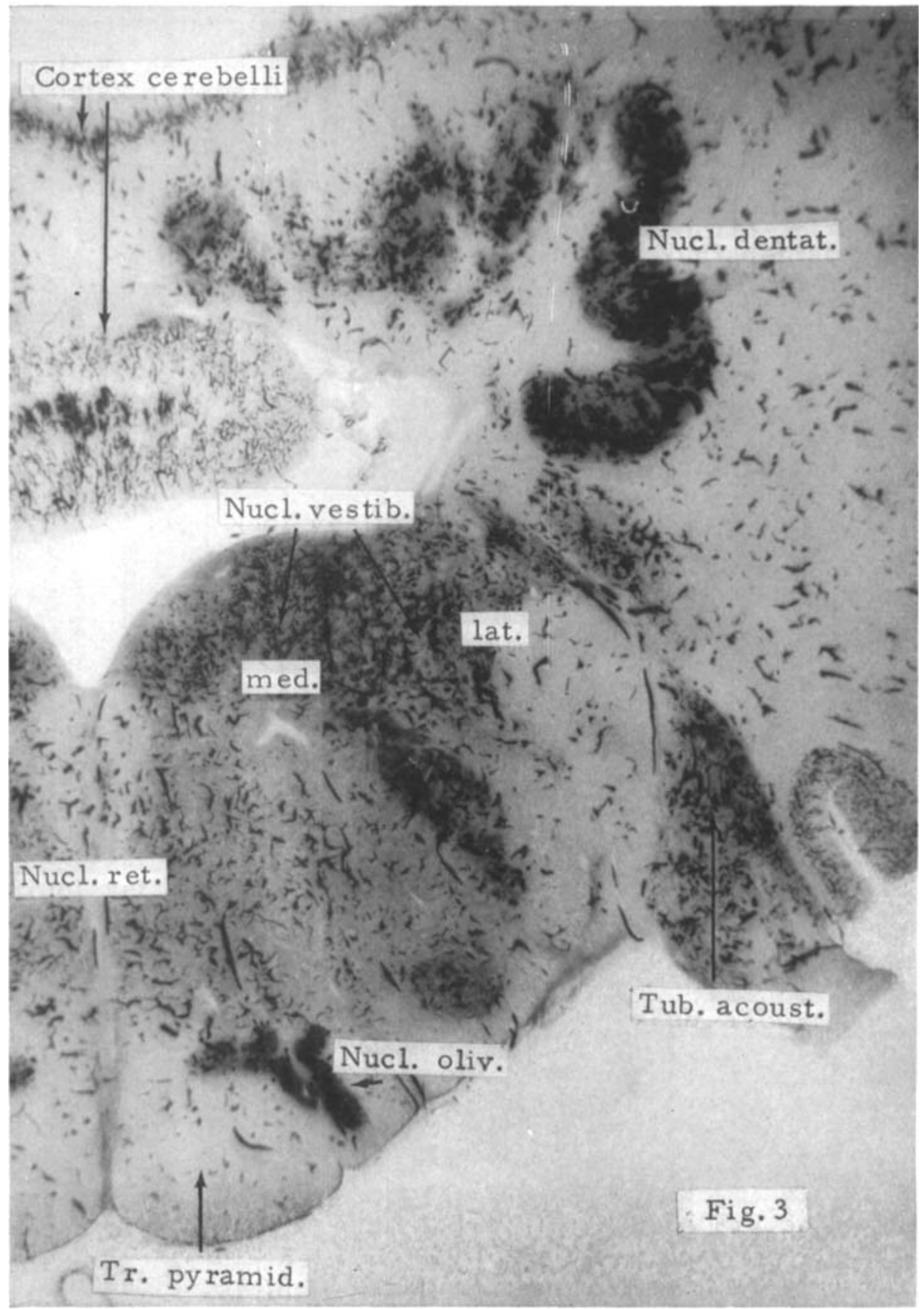

FIG. 3.-Cross section of the medulla oblongata including the cerebellum and the cerebellar nuclei. Note the disproportionately high activity in the dentate nucleus. 


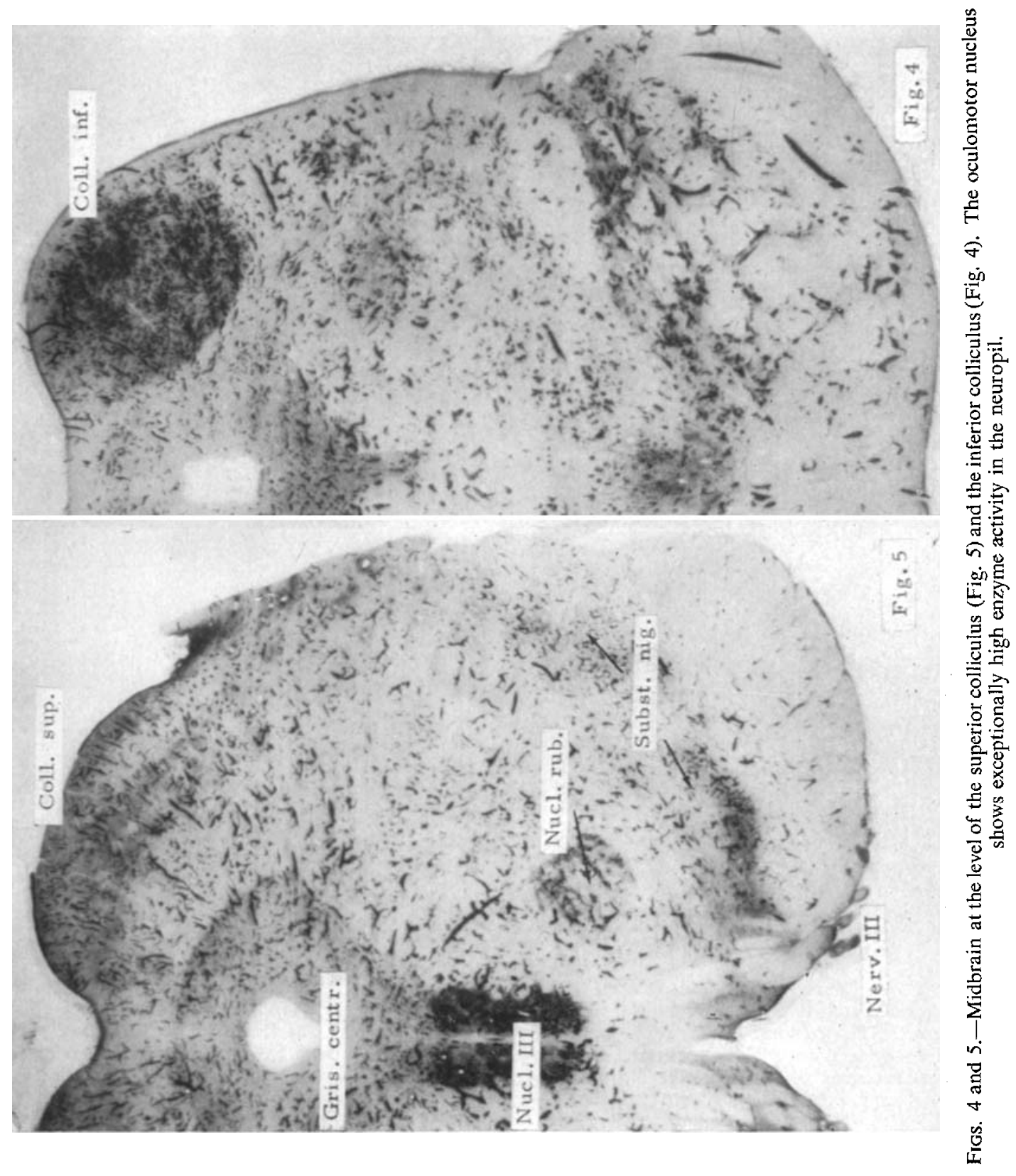




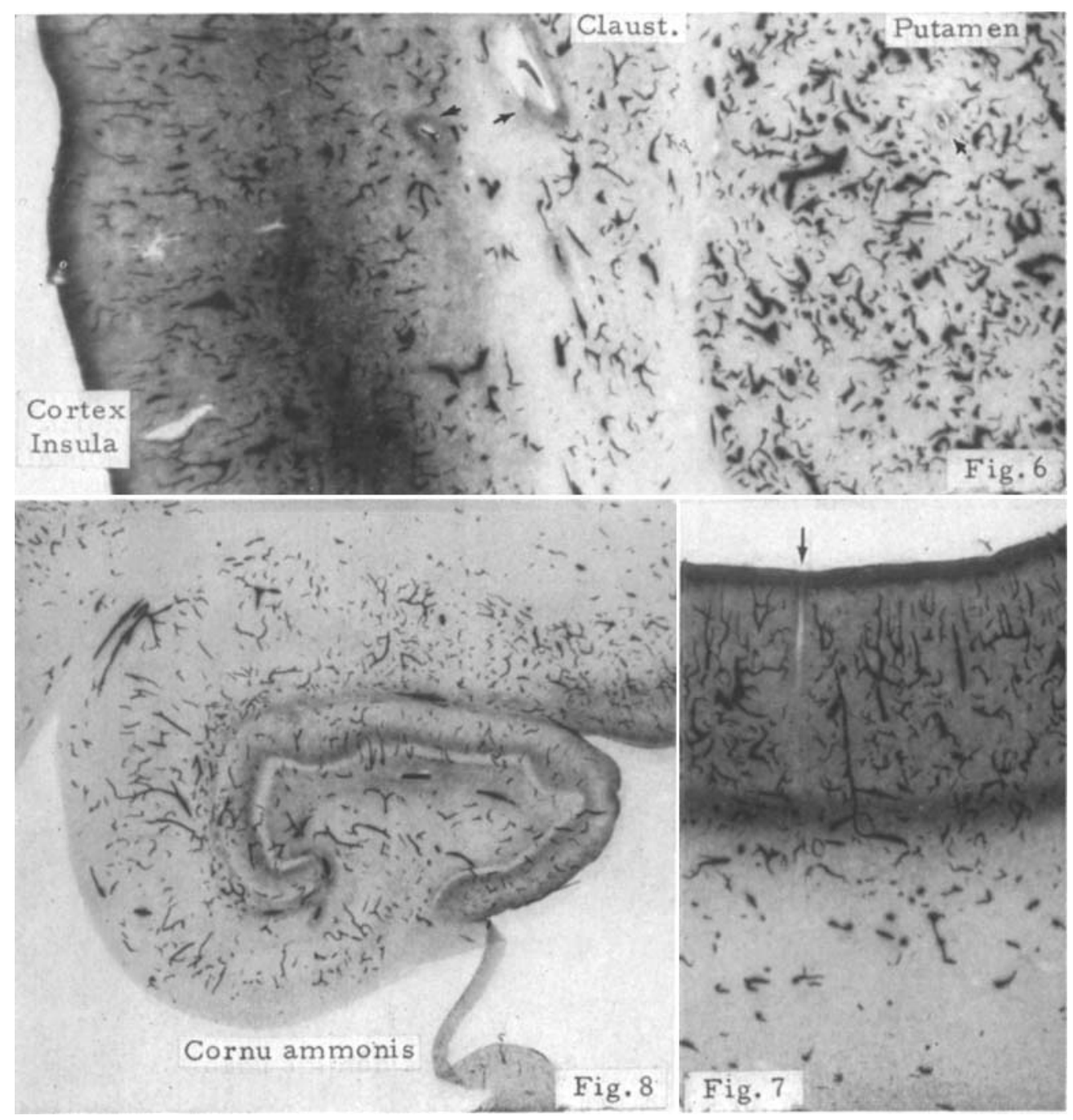

FIG. 6.- Insular cortex (left) and putamen (right) show a striking contrast between the absence of alkaline phosphatase activity in the neuropil of the putamen and the marked activity in the neuropil of the cerebral cortex. The claustrum, in the middle, can be distinguished only by its higher density of capillarization.

FIG. 7.-Parietal cortex showing marked enzyme activity in arteries, arterioles, and capillaries, whereas veins (arrow) appear as light stripes lacking enzyme activity. In the neuropil, there is higher activity at the cortical surface and in a narrow layer situated at the level of the fifth lamina. Note the scarcity of blood vessels with enzyme activity in the deep portions of white matter.

FIG. 8.-Ammon's horn; note the absence of enzyme activity from the neuropil as compared with neocortical regions (Figs. 6, 7). In the fascia dentata, layers of alkaline phophatase activity are found on both sides of the pyramidal cell layer. 
phosphatase to make capillary counts. Other implications that have been considered are the possible significance of alkaline phosphatase activity in blood vessels for the blood-brain barrier (SAMORAJSKI and MCCLOUD, 1961), and the possible physiological significance of high concentrations of enzyme activity in arterioles (BANNISTER and RomanuL, 1963). The extensive regional differences shown by the present study discourage formulation and generalization of such concepts at this time.

\section{SUMMARY}

A quantitative histochemical method, controlled by biochemical assays, has been used for a systematic mapping of alkaline phophatase activity in the brain. Measurements in fifty-two regions are reported. Comparison of the quantitative data with cytological patterns shows that enzyme activity generally prevails in capillaries, but that there are regional differences in the enzyme content in blood vessels; also, regional differences exist in the relative enzyme distribution in neuropil and in blood vessels.

\section{REFERENCES}

ALBert E. (1955) Hoppe-Seylers Z. physiol. Chem. 302, 129.

Bannister R. G. and Romanul F. C. A. (1963) J. Neurol. Neurosurg. Psychiat. 26, 333.

FrIEDE R. L. (1961) A Histochemical Atlas of Tissue Oxidation in the Brain Stem of the Cat. Karger, Basel, New York.

FRIEDE R, L. and KNoller M. (1965a) J. Histochem. Cytochem. 13, 125.

FRIEDE R. L. and KNOLLeR M. (1965b) J. Neurochem. 12, 441.

GOMORI G. (1949) J. Lab. clin. Med. 34, 275.

Landow H., Kabat E., and Newman W. (1942) Arch. Neurol. (Chic.) 48, 518.

Lierse W. V. (1963) Acta anat. (Basel) 54, 1.

LoWry O. H., Roberts N. R., Leiner K., Wu M. L., FARr A. L. and Albers R. W. (1964) J. biol. Chem. 207, 39.

Pearse A. G. E. (1961) Histochemistry. Little, Brown, Boston.

Robins E. and Smith D. E. (1953) Res. Publ. Ass. nerv. ment. Dis. 32, 305.

SAMORAJSKI T. and Fitz F. R. (1961) Lab. Invest. 10, 129.

SAMORAJSKI T. and McCloud J. (1961) Lab. Invest. 10, 492.

SCHARRER E. (1950) Anat. Rec. 107, 319.

SHIMIzU N. (1950) $J$. comp. Neurol. 93, 201.

Wislocki G. B. and DempseY E. W. (1948) J. comp. Neurol. 88, 319. 